\title{
WENDELL M. STRONG
}

Wendell Melville Strong, who died at the age of 7 after a long illness, had been President of the Actuarial Society of America from $193^{\circ}$ to 1932 and he was, at his retitement early in 1941 , VicePresident and Actuary of the Mutual Life Insurance Company of New York, a company which he had served for $4 \mathrm{I}$ years. After leaving Montclair High School he graduated at Yale in 1893 and then studied mathematics at Cornell, at Göttingen (Germany) and again at Yale where he obtained a Ph.D. degree and became an instructor in mathematics from 1895 to 1900 . He then gave up an academic career and joined the actuarial department of the Mutual, studied law at New York University, received the LL.B, degree in $19 \circ 3$, and became a member of the New York bar. He used his legal knowledge in the Legal Notes in the Transactions of the Actuarial Society for two separate periods of I4 years in all, and these notes were excellent in their conciseness and clarity. He also wrote two papers for the Transactions on legal subjects, one on the 'Incontestable Clause in Life Insurance policies', and the other on 'Disability Benefits, the Contract and the Courts'. His other papers were more definitely actuarial and began with one on annuities on joint lives; his next contribution was an interesting study of the mortality among graduates of Yale Divinity School (1825-72), and later there were two papers on Interest Rates, a paper on the Disability Experience of the Mutual and two papers (jointly with Weisse) on Overweights and on Women as Life Insurance Risks. He edited the Transactions of the Actuarial Society from 1909 to I9I6.

Strong came of an old American family; his forebears went to America early in the seventeenth century. He loved England and spent many vacations here and on the Continent, and English actuaries will remember his attendances at several congresses, a paper to the London congress and contributions to the discussions. His slow, deliberate speech indicated the care he took and the accuracy he sought but concealed a remarkable quickness in thought and action. He was a well-read and interesting man; a kind, generous-hearted friend.

We may look back on such friendships with thankfulness; we are sad when they end--but can they ever end? 